\title{
Pathophysiology of CD4+ T-Cell Depletion in HIV-1 and HIV-2 Infections
}

\author{
K. K. Vidya Vijayan, Krithika Priyadarshini Karthigeyan, Srikanth P. Tripathi and \\ Luke Elizabeth Hanna*
}

Division of HIVIAIDS, Department of Clinical Research, National Institute for Research in Tuberculosis (ICMR), Chennai, India

\section{OPEN ACCESS}

Edited by:

Charles R. Rinaldo, University of Pittsburgh, United States

Reviewed by: Talia H. Swartz,

Icahn School of Medicine at Mount Sinai, United States

Gilad Doitsh,

University of California at San Francisco, United States

*Correspondence: Luke Elizabeth Hanna hannatr@@yahoo.com

Specialty section: This article was submitted to HIV and AIDS,

a section of the journal

Frontiers in Immunology

Received: 30 January 2017 Accepted: 01 May 2017

Published: 23 May 2017

Citation:

Vidya Vijayan KK, Karthigeyan KP, Tripathi SP and Hanna LE (2017)

Pathophysiology of CD4+ T-Cell

Depletion in HIV-1 and $H I V-2$ Infections.

Front. Immunol. 8:580. doi: 10.3389/fimmu.2017.00580
The hall mark of human immunodeficiency virus (HIV) infection is a gradual loss of CD4+ T-cells and imbalance in CD4+ T-cell homeostasis, with progressive impairment of immunity that leads ultimately to death. HIV infection in humans is caused by two related yet distinct viruses: HIV-1 and HIV-2. HIV-2 is typically less virulent than HIV-1 and permits the host to mount a more effective and sustained T-cell immunity. Although both infections manifest the same clinical spectrum, the much lower rate of CD4+ T-cell decline and slower progression of disease in HIV-2 infected individuals have grabbed the attention of several researchers. Here, we review the most recent findings on the differential rate of decline of CD4+ T-cell in HIV-1 and HIV-2 infections and provide plausible reasons for the observed differences between the two groups.

Keywords: CD4+ T-cell, immune activation, pyroptosis, HIV-1, HIV-2

\section{INTRODUCTION}

Acquired immune deficiency syndrome (AIDS) is one of the most devastating infectious diseases affecting humankind, with an estimated 36.7 million people living with human immunodeficiency virus (HIV) infection as per 2015 estimates (1). Although the majority of this infection is caused by HIV-1, a closely related viral strain, HIV-2 that is believed to have spread in parallel with HIV-1 is also an etiological agent of this dreadful infection. The two viruses share striking similarities in genetic and biological properties, such as genome structure and mechanisms for transactivation and CD4+ cell depletion, and yet, HIV-2 exhibits much longer clinical latency periods, significantly lower rates of disease progression and transmission and lower viral load in the asymptomatic phase as compared to HIV-1 infection $(2,3)$. The distinct differences in pathogenicity provide a unique opportunity to look for protective viral and host immune mechanisms that contribute to viral control.

A significant amount of research has recently been focused on identifying causal factors for the difference in pathogenicity between the two infections in the hope of obtaining clues that could ultimately lead to a sustainable cure in some way. In this context, considerable amount of attention has been paid to understand the hallmark feature of HIV infection, i.e., progressive depletion of CD4 lymphocytes, and its distinct regulation in HIV-infected individuals in whom infection never progresses to AIDS or progresses very slowly. While in the case of HIV-1 infection there is a steady decline in CD4+ T-cell count, in HIV-2 infection, the decline is much slower and viremia levels are lower at any stage of the disease (4-6). In this article, we review the distinct pathological differences between HIV-1 and HIV-2 infections in the perspective of differential rate of CD4+ T-cell decline and provide plausible reasons for the observed differences. 


\section{DEPLETION OF CD4+ T-CELL-A KEY EVENT IN HIV DISEASE PROGRESSION}

CD4+ T-cells are the central mediators of immune response in humans, crucially coordinating cellular and humoral immune responses against infections. Very early studies on subjects with AIDS documented lymphopenia, low lymphocyte proliferative responses after stimulation with antigens, and an inversion in the ratio of helper T-cells to cytotoxic T-cells (7-9). Further studies in this line confirmed that HIV selectively infects CD4+ T-cells and destroys them for its own benefits (10). Later, it was shown that suppressing HIV replication with antiretroviral therapy (ART) rapidly increased peripheral blood $\mathrm{CD} 4+\mathrm{T}$-cell counts and reversed immunodeficiency $(11,12)$. Now, most researchers agree that HIV majorly infects CD4+ T-cells and leads to progressive loss of the cells from circulation and from the total body stores.

Upon in vitro infection with HIV, productive infection of CD4+ T-cells takes place and leads to either cell lysis or giant cell/ syncytia formation, in which both infected and uninfected cells fuse, leading to spread of infection (10). Animal models of SIV infection also documented severe depletion of CD4+ T-cells in the gut-associated lymphoid tissue (GALT), which is the major producer of CD4+ T-cells in the body (13). Subsequent studies provided evidence that the same phenomenon of depletion of GALT CD4 reservoirs occurs in human HIV infection as well (13). Quantitative estimates of absolute CD4+ T-cell count and percentage have been shown to correlate strongly with the progression of disease. A normal adult harbors about $22 \times 10^{11} \mathrm{CD} 4+$ T-cells (14), whereas in the HIV-infected individual, this number is halved by the time the peripheral blood CD4+ T-cell count falls to 200 cells/microliter of blood $(14,15)$. In more advanced disease, destruction of parenchymal lymphoid spaces is so extensive that enumeration of the total body CD4+ T-cell count cannot even be attempted. Since HIV induces both quantitative and qualitative defects in the CD4+ T-cell compartment, numbers of circulating CD4+ T-cells in HIV+ subjects have been the most widely used tool for predicting the onset of overt immunodeficiency and the best surrogate marker for monitoring severity of the disease (16).

\section{CONTRIBUTORS TO CD4+ T-CELL DEPLETION}

CD4+ T-cells are known to be the central facilitators for both cellular and humoral immune responses against exogenous antigens and are kept constant in the human body by homeostatic mechanisms $(17,18)$. HIV binds to the CD4 molecule on the surface of helper T-cells and replicates within them. This results in destruction of CD4+ T-cells and leads to a steady decline in this population of T-cells. The definition of progressive and slow loss of CD4+ T-cells is not clear. In order to understand the correlation between CD4+ T-cell depletion and immunopathogenesis, and its relationship with disease progression, a number of dynamic models have been put forward. Two of the most acknowledged mechanisms are discussed in detail in this review. These include direct virus attack leading to cytolytic effect and chronic immune activation resulting in apoptosis.

\section{Direct Attack by HIV}

Several studies carried out in the late 1980s and early 1990s provided support for the hypothesis of "accelerated destruction" of CD4+ T-cells by viral attack. This hypothesis received indirect experimental validation from Ho and colleagues $(19,20)$, who proposed "the tap and drain hypothesis" for the slow depletion of CD4 cells. According to this theory, there is a homeostatic response by which the loss of CD4+ T-cells due to HIV infection (the drain) is comfortably counteracted by production of T-cells (a wide open tap); however, this balance is ultimately disrupted once the production of T-cells in response to homeostasis is exhausted. This has been substantiated by quantitative image analysis of decreased numbers of CD4+ T-cells and increased levels of cellular proliferation and apoptosis in HIV-infected individuals $(21,22)$.

Given the fact that HIV infection accelerates both the production and the destruction of CD4+ T-cells, in the early stages of the infection, there is constant replacement of dying CD4+ T-cells with native CD4+ T-cells originating from the thymus (21). It is reported that during the course of HIV infection, about 1 billion of HIV particles are produced per day, resulting in increasing numbers of infected CD4+ T-cells $(21,23)$. Subsequently, infection spreads to the memory cells in the thymus and the virus starts to replicate there. Each time a memory CD4+ T-cell is infected by HIV, it is destined to undergo the process of elimination, thus contributing to the progressive decline in CD4+ T-cell numbers (22). Analysis of T-cell turnover in humans with HIV infection suggests that the fraction of dividing CD4+ T-cells in untreated HIV disease can be elevated two- to threefold $(24,25)$, with most proliferation concentrated in the CD45RO+ memory/effector population of CD4+ T-cells (26). While direct viral killing/cytolysis of CD4 T-cells partly clarifies the cause of depletion of CD4+ T-cells, the loss of uninfected CD4 cells and naive CD8 cells during the asymptomatic phase of HIV infection cannot be explained by this hypothesis. Taken together, these observations suggest that AIDS pathogenesis cannot solely be explained by the direct viral killing hypothesis.

\section{Chronic Immune Activation}

Another dynamic model that emerged to explain the pathogenesis of AIDS and accompanying CD4 depletion is the "hyper immune activation hypothesis," which suggests that there is a high rate of cell division among the CD4+ and CD8+ T-cell, NK cell, and $\mathrm{B}$ cell populations during the course of HIV infection and an associated upregulation of activation markers (27). Several studies have demonstrated that the level of immune activation in HIV-infected subjects is a better predictor of disease progression than the levels of virus replication $(28,29)$. Hyperimmune activation induces increased cell division in memory T-cells and increases their capacity for self-renewal, thereby leading to increased cell counts. To explain "depletion by activation," Yates et al. proposed that the activated CD4+ T-cells have a very short life span and are lost rather quickly due to activation-induced cell death or apoptosis(30). Labeling studies have shown evidence of increased turnover of naïve T-cells in HIV infection. This is also supported by the dilution of excision circles of the T-cell receptor (31). Thus, chronic immune activation better explains immune 
deficiency among HIV-infected individuals, and the level of activation predicts disease progression in HIV-infected subjects better than viral replication-driven pathogenesis (32-34).

Investigation on HIV infection has shown that immune system remains in a hyperactive state characterized by high T-cell turnover, non-specific T-cell activation and proliferation, polyclonal activation of B cells, and elevated proinflammatory cytokines (35). Thus, HIV makes its own target and increases replication through immune activation. HIV infection activates the immune system through the viral gene products Nef, Tat, Vpr, and Vpu (30, 36) and also through production of inflammatory cytokines (37). For instance, Nef and Vpr are involved in stimulating monocytes and macrophage cells (37). Likewise, plasmacytoid dendritic cells (DCs) are induced by HIV RNA; they interact with the pattern recognition receptors such as toll-like receptor (TLR)-7 and TLR-9 and induce the production of interferon (IFN)- $\alpha$ (38). In addition, the presence of HIV DNA in the cytoplasm itself leads to the activation of caspase- 1 and to the release of proinflammatory cytokines including interleukin (IL)-1 $\beta$ (38). Thus, even abortive HIV-1 infection, if it results in the presence of viral DNA in the cytoplasm of target cells, could induce immune activation.

\section{Immune Activation and Inflammation}

In general, HIV-associated chronic immune activation is characterized by high levels of circulating proinflammatory cytokines and chemokines, including type I IFNs, IL-6, TGF $\beta$, IL- 8 , IL- $1 \alpha$, IL-1 $\beta$, MIP- $1 \alpha$, MIP-1 $\beta$, and RANTES $(39,40)$. Plasma proteins such as neopterin, $\beta 2$-microglobulin $(\beta 2 \mathrm{M})$, TNF- $\alpha$, soluble TNFRII, soluble IL-2R, and IFN- $\gamma$ are documented to be increased even in the early stages of infection $(34,40)$. Many other proteins, including anti-inflammatory cytokines IL-10 and TGF- $\beta 1$ and IFN-inducible protein-10 (IP-10), have also been shown to be increased in the plasma during acute infection and are reported to be predictive of rapid disease progression (41). Thus, massive increase of cytokine release, called cytokine storm, characterizes acute and chronic HIV infection and contributes to predict the immune activation and CD4+ T-cell depletion. Persistent immune activation also prevents the establishment of IL-2-producing memory CD4+ and CD8+ T-cells (42), and this has deleterious effects on HIV-specific CD4+ T-cell immunity (43).

During early infection, the virus primarily disturbs the mucosal immune function. Loss of integrity of the gastrointestinal mucosa and microbial translocation contribute to induction of local inflammation and HIV-associated chronic immune activation, which in turn are associated with disease progression and CD4+ T-cell depletion (44). Several studies have shown that poorly controlled translocation of immunostimulatory microbial products occurs in HIV-infected individuals. Through the stimulation of several TLRs, these microbial products activate various immune cell types and induce production of proinflammatory cytokines, such as TNF- $\alpha$, IL- 6 , IL- $1 \beta$, and type I IFNs (44-46). These responses significantly contribute to the aberrant immune activation in chronic HIV infection. The breach of the gut system has been shown to correlate well with the level of immune activation and depletion of CD4+ Th17 cells, a cell type that is normally abundant in the mucosa and is known to be involved in immunity to commensal bacteria (47). The selective loss of Th17 CD4+ T-cells from the gut possibly due to selective infection has therefore been held responsible for the long-term loss of the intestinal integrity and thereby for chronic immune activation in pathogenic HIV infection (47-49). In short, HIV infection is characterized by massive production of proinflammatory cytokines $(48,49)$, which in turn leads to clonal deletion (49) and gradual loss of peripheral CD4+ T-cells over time (50).

\section{Pyroptosis and Apoptosis}

It has been known for some time now that apoptosis is a major factor contributing to T-cell depletion, mediated by caspase- 3 , in T-cells that are permissive to infection by HIV. However, there are subsets of T-cells (abortive T-cells) that are non-permissive and do not support HIV replication. In this subset of cells, cell death occurs through a process called pyroptosis, driven by caspase-1 (51). Pyroptosis is a highly inflammatory form of programmed cell death in which the dying cell releases all its cytoplasmic contents, including inflammatory cytokines; these cytokines in turn trigger pyroptosis in other T-cells as part of a vicious cycle of abortive T-cell depletion (52). Recent studies by Doitsh et al. showed that depletion of T-cells and subsequent progression of disease occur not only through apoptosis but also through pyroptosis (51). In a subsequent study, the same group of investigators showed that only $5 \%$ of CD $4+$ T-cell depletion occurs through apoptosis, while the remaining 95\% of quiescent lymphoid CD4+ T-cells die by caspase-1-mediated pyroptosis triggered by abortive viral infection $(51,52)$. Pyroptosis thus links the two signature events in HIV infection-CD4+ T-cell depletion and chronic inflammation-and creates a pathogenic vicious cycle in which dying CD4+ T-cells release inflammatory signals that stimulate more cells to die. Thus, it establishes a state of chronic inflammation that eventually fuels disease progression.

\section{Regulatory T-Cells (Treg)}

CD4+ Treg gained prominence recently. These cells play a vital role in T-cell homeostasis and limiting of immunopathology through the suppression of specific T-cell responses such as activation, proliferation, and effector function (53). A study undertaken by Foxall et al. in 2011 demonstrated that CD4 depletion is associated with relative expansion of Treg cells, irrespective of the presence or absence of circulating virus, leading to better preservation of circulating naive and memory Treg cells as compared to other CD4+ T-cell subsets in HIV/AIDS (54). Increased frequency of CD4+ T-cells expressing CD25 has been observed in HIV-2infected individuals, independent of the degree of CD4 depletion and levels of immune activation. CD4+CD25+ T-cells, a subset that expresses the highest level of the lineage regulatory marker FoxP3, are proposed to play a significant role in models of experimental chronic infection by contributing to suppression of T-cell responses (55). On the other hand, CD4+ T-cells expressing an intermediate intensity of CD25 are characterized by an increased ability to produce IL-2 and lack other regulatory markers. The expansion of this population of cells is not seen in HIV-1 infection. The presence of higher levels of these cells in HIV-2-infected individuals may point to an improved ability to replenish their CD4 memory pool and to the lower virulence of HIV-2 infection as compared to that of HIV-1. Furthermore, the Treg cell population can be subdivided into CD45RA+ (naïve-resting cells) and 
CD45RA - (memory-activated cells). The majority of Tregs in the HIV-2-infected individuals have been observed to lack CD45RA expression, thus implying that most of the Tregs in these individuals belong to the memory-activated phenotype. These findings further support a close link between CD4 depletion and immune activation. Thus, it is plausible that Tregs also have a role in the slower rate of disease progression associated with HIV-2 infection $(54,56)$.

\section{DISTINGUISHING FEATURES OF CD4+ T-CELL DEPLETION IN HIV-1 AND HIV-2 INFECTIONS}

One of the best ways of elucidating the intriguing nature of immunopathogenesis of HIV infection is studying naturally occurring HIV infection with different clinical outcomes. HIV-2 infection provides an ideal situation for this investigation as it has a lower degree of pathogenicity as compared to HIV-1. Although HIV-2 also eventually causes immunodeficiency syndrome indistinguishable from HIV-1-induced AIDS (57, 58), many HIV-2-infected individuals do not develop immunodeficiency during their lifetime and retain stable CD4+ T lymphocyte counts and low levels of viremia for many years (4-6). This striking difference has prompted the search for the reason for variations in T-cell homeostasis and imbalances in cytokine production and identification of factors that contribute to an effective immune response that delays progression of disease during infection.

One of the major aspect of CD4+ T-cell depletion and its associated immunopathology that distinguishes between HIV-1 and HIV-2 infections is immune activation (59), which is a strong predictor of disease progression HIV infection (60). One of the key drivers for immune activation during chronic HIV-1 and HIV-2 infection is the breach of the gastrointestinal tract, resulting in

TABLE 1 | Comparison of HIV-1 and HIV-2 infection.

\begin{tabular}{|c|c|c|}
\hline & Human immunodeficiency virus (HIV)-1 & HIV-2 \\
\hline \multicolumn{3}{|c|}{ Epidemiological and clinical significance between HIV-1 and HIV-2 infection } \\
\hline Geographical distribution & Global & $\begin{array}{l}\text { Confined to West Africa with limited spread; also reported in } \\
\text { former Portuguese colonies, such as Angola, Mozambique, } \\
\text { and Brazil, and in parts of India }\end{array}$ \\
\hline Heterosexual transmission & Sexual mode of transmission is higher & Fivefold lower rate than HIV-1 \\
\hline Vertical transmission & Mother to child transmission is higher & 20- to 30-fold lower rate than HIV-1 \\
\hline Duration of asymptomatic stage & $\begin{array}{l}\text { Time to develop acquired immune deficiency syndrome } \\
\text { (AIDS) varies, ranging from a few months to many years, with } \\
\text { an estimated median time of } 9.8 \text { years }\end{array}$ & Longer duration, ranging from $10-25$ years \\
\hline Clinical illness & $\begin{array}{l}\text { If untreated, around half of people infected with HIV-1 will } \\
\text { develop AIDS within } 10 \text { years }\end{array}$ & $\begin{array}{l}86-95 \% \text { of people infected with HIV-2 are long-term } \\
\text { non-progressors }\end{array}$ \\
\hline Proviral DNA load & Similar & Similar \\
\hline Plasma RNA load & Higher & Significantly lower than HIV-1 \\
\hline Viral replication kinetics & Higher replication and 100 -fold more fit & Transient replication and less fit \\
\hline Infectivity and transmission fitness & Similar and 100-fold more fit & Similar and less fit \\
\hline Co-receptor usage & Uses CXCR4 and CCR5 & $\begin{array}{l}\text { Uses a range of co-receptors, including CCR1, CCR2, CCR3, } \\
\text { CXCR6, BOB, CCR5, and CXCR } 4\end{array}$ \\
\hline \multicolumn{3}{|c|}{ CD4+ T-cell responses between HIV-1 and HIV-2 infection } \\
\hline CD4+ T-cell count & $\begin{array}{l}\text { Lower compared to HIV-2 with undetectable viral load but } \\
\text { similar to HIV-2 with higher viral load }\end{array}$ & $\begin{array}{l}\text { Higher in HIV-2 with undetectable viral load and similar to } \\
\text { HIV-1 with higher viral load }\end{array}$ \\
\hline CD4+ T-cell response & $\begin{array}{l}\text { Lesser proliferative capacity and polyfunctionality, and } \\
\text { increased differentiation }\end{array}$ & $\begin{array}{l}\text { Better proliferative capacity, more polyfunctionality, and lesser } \\
\text { differentiation }\end{array}$ \\
\hline Thymic function & $\begin{array}{l}\text { HIV-1 can replicate efficiently in thymus tissue. No correlation } \\
\text { with the rate of CD4+ T-cell loss }\end{array}$ & $\begin{array}{l}\text { HIV-2 is able to infect the human thymus, but this is associated } \\
\text { with limited viral replication. Correlates with lower rates of } \\
\text { CD4+ T-cell }\end{array}$ \\
\hline Production of cytokines & $\begin{array}{l}\text { Interleukin (IL)-2- and IL-4-producing cells decline as disease } \\
\text { progresses }\end{array}$ & $\begin{array}{l}\text { IL-2- and IL-4-producing cells better preserved. Expressions of } \\
\text { both IL-2- and IFN- } \gamma \text {-producing cells are more }\end{array}$ \\
\hline CD57-CD4+ T-cell expression & Less frequently seen & More CD57- cells are seen \\
\hline CD4+ T-cell activation level & $\begin{array}{l}\text { Positive correlation between lipopolysaccharide (LPS) level } \\
\text { and proinflammatory cytokines IL-12 and IFN- } \gamma\end{array}$ & $\begin{array}{l}\text { Negative correlation between LPS level and proinflammatory } \\
\text { cytokines in HIV-2 individuals with undetectable VL }\end{array}$ \\
\hline Susceptibility to the SAMHD1 & Myeloid cells are refractory to viral infection & $\begin{array}{l}\text { Presence of Vpx permits viral infection of myeloid cells through } \\
\text { degradation of SAMHD1 }\end{array}$ \\
\hline Immune activation and T-cell apoptosis & Higher immune activation and more apoptosis & Less immune activation and less T-cell apoptosis \\
\hline Nef & Does not downmodulate the TCR-CD3 complex & Downregulates the TCR-CD3 complex \\
\hline
\end{tabular}


translocation of bacterial lipopolysaccharide (LPS) into the blood $(28,34)$. LPS is a known activator of innate immune cells via TLR4 , and LPS concentrations in the circulation of HIV-infected individuals correlated strongly with T-cell activation levels $(61,62)$. A study by Nowroozalizadeh et al. showed an inverse correlation between plasma LPS levels and expression of proinflammatory cytokines IL-12 and IFN- $\gamma$ following TLR stimulation in HIV-2infected, HAART-naive individuals, whereas in HIV-2-infected individuals with AIDS, there was a positive correlation between LPS levels, CD4+ T-cell lymphopenia, and HIV RNA load similar to HIV-1 infection (63).

The viral proteins Nef, Env, and Tat also play a part in immune activation. In HIV-2 infection, intracellular Nef promotes the downregulation of the T-cell receptor complex in CD4+ T-cells, whereas in HIV-1 infection, Nef seems to have lost its ability to downmodulate the expression of CD3-TCR complex on the surface of infected T-cells (64). As a consequence, HIV-1 Nef may directly contribute to immune activation by rendering infected CD4+ T-cells highly sensitive to restimulation through the $\mathrm{T}$-cell receptor. In contrast, the low level of immune activation in HIV-2-infected individuals with low virus replication may prevent the shift in T-cell function and phenotype in chronic infection. Studies have also shown that low levels of circulating virus lead to low levels of activation of CD4 and CD8 cells; gag mRNA level has been found to correlate with CD4+ T-cell activation and tat mRNA with CD8+ T-cell activation $(65,66)$. Studies have also shown that tat mRNA transcripts accumulate and outnumber gag mRNA transcripts in recently infected cells with HIV-1 (67), whereas HIV-2 infected cells had reduced levels of tat mRNA transcripts, indicating a decreased rate of de novo cell infection in HIV-2 disease (66). This lower level of immune activation in HIV-2 cohorts as compared to HIV-1-infected groups (67) may explain the relative sparing of $\mathrm{T}$ lymphocytes from cell death in HIV-2 infection, which is consistent with the "less activation/ better outcome" paradigm.

The function of the thymus is well preserved in HIV-2-infected individuals, allowing CD4+ T-cells to retain better proliferative capacity, remain less differentiated, and elicit more polyfunctional responses, than in HIV-1 infected individuals (68). HIV-2-infected individuals are also highly efficient in replacing infected CD4+ T-cells (69). Earlier studies have revealed the central role of IL-2 and IFN $\gamma$ as survival and proliferative factors $(70,71)$ in HIV-1 infection; as disease progresses, the frequency of IL-2-producing CD4+ T-cells is found to decline (42), which in turn relates to the reduced renewal capacity and increased susceptibility of these populations of cells to apoptosis (70). However, in HIV-2 infection, the proportion of CD4+ T-cells expressing IL-2 is well preserved (42). HIV-2-infected individuals also possess a higher frequency of CD4+ T-cells capable of expressing both IFN $\gamma$ and IL-2 in response to Gag-specific peptides than HIV-1 infected individuals $(72,73)$. Further immunological studies revealed the presence of Gag-specific CD4+ T-cells lacking CD57 expression in HIV-2 infection $(74,75)$, indicating better proliferative capacity resulting in higher number of cells in HIV-2 infected individuals (75). In lieu with these observations, normal CD4 counts in HIV-2-infected individuals were three times greater than in HIV-1-infected individuals with comparable levels of
CD4+ T-cells (74). These findings provide conclusive evidence for the lower lymphocyte susceptibility to apoptosis and slower rate of CD4+ T-cell decline in HIV-2-infected individuals as compared to those with HIV-1 infection.

\section{CONCLUDING REMARKS}

With decades of experimental research and volumes of observational data, the complete mechanism of CD4+ $\mathrm{T}$ depletion in HIV infection still remains to be explained. HIV-2, a natural model of attenuated HIV infection, provides an appropriate system for exploring paradigms for pathogenesis and helps in understanding retroviral pathology. This review highlights the unique aspects of CD4+ T-cell depletion in HIV-1 and HIV-2 infections (Table 1). Collectively, the available data suggests that HIV-2 is associated with more efficient immunologic responses and lower replication efficiency in primary cells including resting CD4+ T-cells and activated CD4+ T-cells which ultimately leads to better virus control and slower disease progression.

Recent studies have identified several other factors that contribute to the difference in pathogenesis between HIV-1 and HIV-2 infections. One of these includes cellular sensors that are involved in the recognition of HIV and induction of innate and adaptive immune responses (76). Certain key differences between innate sensing mechanisms in HIV-1 and HIV-2 infections have been identified. One of the major cell types involved in differential innate immune sensing between HIV-1 and HIV-2 is the DCs (77). DCs do not normally get activated and are not efficiently infected by HIV-1 $(78,79)$, since SAMHD1, which is an intracellular exonuclease, restricts HIV replication and transcription in dendritic and myeloid cells by hydrolyzing deoxynucleoside triphosphates during reverse transcription of viral RNA (79). In contrast, DCs are naturally activated and infected by HIV-2 (80); the Vpx protein that is produced by HIV-2 and not by HIV-1 is responsible for overcoming the SAMHD1 restriction in DCs $(77,80)$. Intrinsic pattern recognition receptors within the DCs sense HIV-2. The signals from the PRRs direct the antigen-presenting DCs to mature and generate effective acquired immune responses against HIV-2. This view is supported by the finding that polyfunctional, virus-specific, T-cell responses are more commonly seen in HIV-2 than in HIV-1 infection (80). SAMHD1 degradation thus could have both positive and negative effects on the efficiency of HIV-2 replication in vivo. On the one hand, it allows efficient infection of macrophages and DCs with HIV-2, thus expanding the number of viral target cells, and on the other hand, SAMHD1 degradation by Vpx may contribute to the effective control of viral replication in HIV-2-infected individuals by inducing potent immune responses through viral immune sensing by infected DCs (81).

The ability of HIV to seed latent reservoirs in the body very early during infection is one of the major barriers for eradication of the virus. The stable latent reservoirs in the body comprise long-lived, transcriptionally inactive, and immunologically inert cells lodged in anatomical sites with poor drug penetration. The major constituents of the viral reservoir are the latently infected resting memory CD4+ T-cells and macrophages $(82,83)$. HIV latency can be of two types: pre-integration and post-integration. Although not much is known about the contribution of pre-integration latency to HIV-2 
infection, post-integration HIV-2 latency, through post-transcriptional control of viral replication, has been described after in vitro infection of specific subsets of target cells (84). Subtle differences in the transcriptional control elements present in the HIV-2 LTR are thought to contribute to the differences in transcriptional activity and, in a way, to the differences in the pathogenesis between the two viruses. More studies in this line will help to further clarify the mechanisms that contribute to better control of HIV-2 infection and pave way for the design of effective strategies to prevent disease progression in HIV-infected individuals.

\section{REFERENCES}

1. UNAIDS. Report on the Global AIDS Epidemic. (2016). Available from: http:// www.unaids.org

2. Marlink R, Kanki P, Thior I, Travers K, Eisen G, Siby T, et al. Reduced rate of disease development after HIV-2 infection as compared to HIV-1. Science (1994) 265(5178):1587-90. doi:10.1126/science.7915856

3. Marlink R. Lessons from the second AIDS virus, HIV-2. AIDS (1996) 10(7):689-99. doi:10.1097/00002030-199606001-00002

4. Jaffar S, Wilkins A, Ngom PT, Sabally S, Corrah T, Bangali JE, et al. Rate of decline of percentage CD4+ cells is faster in HIV-1 than in HIV-2 infection. J Acquir Immune Defic Syndr Hum Retrovirol (1997) 16(5):327-32. doi:10.1097/00042560-199712150-00003

5. Popper SJ, Sarr AD, Travers KU, Gueye-Ndiaye A, Mboup S, Essex ME, et al. Lower human immunodeficiency virus (HIV) type 2 viral load reflects the difference in pathogenicity of HIV-1 and HIV-2. J Infect Dis (1999) 180(4):1116-21. doi:10.1086/315010

6. Popper SJ, Sarr AD, Gueye-Ndiaye A, Mboup S, Essex ME, Kanki PJ. Low plasma human immunodeficiency virus type 2 viral load is independent of proviral load: low virus production in vivo. J Virol (2000) 74(3):1554-7. doi:10.1128/JVI.74.3.1554-1557.2000

7. Wei X, Ghosh SK, Taylor ME, Johnson VA, Emini EA, Deutsch P, et al. Viral dynamics in human immunodeficiency virus type 1 infection. Nature (1995) 373(6510):117-22. doi:10.1038/373117a0

8. Small CB, Klein RS, Friedland GH, Moll B, Emeson EE, Spigland I. Community-acquired opportunistic infections and defective cellular immunity in heterosexual drug abusers and homosexual men. Am J Med (1983) 74(3):433-41. doi:10.1016/0002-9343(83)90970-1

9. Chun TW, Stuyver L, Mizell SB, Ehler LA, Mican JA, Baseler M, et al. Presence of an inducible HIV-1 latent reservoir during highly active antiretroviral therapy. Proc Natl Acad Sci U S A (1997) 94(24):13193-7. doi:10.1073/pnas.94.24.13193

10. Nishimura Y, Brown CR, Mattapallil JJ, Igarashi T, Buckler-White A, Lafont BA, et al. Resting naive $\mathrm{CD} 4+\mathrm{T}$ cells are massively infected and eliminated by $\mathrm{X} 4$-tropic simian-human immunodeficiency viruses in macaques. Proc Natl Acad Sci U S A (2005) 102(22):8000-5. doi:10.1073/pnas.0503233102

11. Reimann KA, Li JT, Veazey R, Halloran M, Park IW, Karlsson GB, et al. A chimeric simian/human immunodeficiency virus expressing a primary patient human immunodeficiency virus type 1 isolate env causes an AIDS-like disease after in vivo passage in rhesus monkeys. J Virol (1996) 70(10):6922-8.

12. Nowak MA, Lloyd AL, Vasquez GM, Wiltrout TA, Wahl LM, Bischofberger N, et al. Viral dynamics of primary viremia and antiretroviral therapy in simian immunodeficiency virus infection. J Virol (1997) 71(10):7518-25.

13. Brenchley JM, Schacker TW, Ruff LE, Price DA, Taylor JH, Beilman GJ, et al. $\mathrm{CD} 4+\mathrm{T}$ cell depletion during all stages of HIV disease occurs predominantly in the gastrointestinal tract. J Exp Med (2004) 200(6):749-59. doi:10.1084/ jem. 20040874

14. Haase AT. Population biology of HIV-1 infection: viral and CD4+ T cell demographics and dynamics in lymphatic tissues. Annu Rev Immunol (1999) 17:625-56. doi:10.1146/annurev.immunol.17.1.625

15. Rosok BI, Bostad L, Voltersvik P, Bjerknes R, Olofsson J, Asjo B, et al. Reduced $\mathrm{CD} 4$ cell counts in blood do not reflect $\mathrm{CD} 4$ cell depletion in tonsillar tissue in asymptomatic HIV-1 infection. AIDS (1996) 10(10):F35-8.

\section{AUTHOR CONTRIBUTIONS}

KV drafted the manuscript. KK helped with literature collections. ST and LH reviewed the manuscript.

\section{ACKNOWLEDGMENTS}

We thank Department of Science and Technology, New Delhi, India, and Indian Council of Medical Research, New Delhi, India, for their support.

16. Okoye AA, Picker LJ. CD4(+) T-cell depletion in HIV infection: mechanisms of immunological failure. Immunol Rev (2013) 254(1):54-64. doi:10.1111/ imr.12066

17. Martin D, Sim J. The laboratory diagnosis of HIV infection. S Afr Med J (2000) 90(2):105-9.

18. McCune JM. The dynamics of CD4+ T-cell depletion in HIV disease. Nature (2001) 410(6831):974-9. doi:10.1038/35073648

19. De Boer RJ. Time scales of CD4+ T cell depletion in HIV infection. PLoS Med (2007) 4(5):e193. doi:10.1371/journal.pmed.0040193

20. Ho DD, Neumann AU, Perelson AS, Chen W, Leonard JM, Markowitz M. Rapid turnover of plasma virions and CD4 lymphocytes in HIV-1 infection. Nature (1995) 373(6510):123-6. doi:10.1038/373123a0

21. Hazenberg MD, Hamann D, Schuitemaker H, Miedema F. T cell depletion in HIV-1 infection: how CD4+ T cells go out of stock. Nat Immunol (2000) 1(4):285-9. doi:10.1038/79724

22. Cooper A, García M, Petrovas C, Yamamoto T, Koup RA, Nabel GJ. HIV-1 causes $\mathrm{CD} 4$ cell death through DNA-dependent protein kinase during viral integration. Nature (2013) 498:376-9. doi:10.1038/nature12274

23. Autran B, Katlama C. Sufficient immune reconstitution is possible in the context of HAART: for and against. Programme and Abstract of XIII International Conferences on AIDS; 2000 Jul 9-14; Durban, South Africa (2000).

24. Fleury S, Rizzardi GP, Chapuis A, Tambussi G, Knabenhans C, Simeoni E, et al. Long-term kinetics of $\mathrm{T}$ cell production in HIV-infected subjects treated with highly active antiretroviral therapy. Proc Natl Acad Sci U S A (2000) 97(10):5393-8. doi:10.1073/pnas.97.10.5393

25. Hellerstein M, Hanley MB, Cesar D, Siler S, Papageorgopoulos C, Wieder E, et al. Directly measured kinetics of circulating T lymphocytes in normal and HIV-1-infected humans. Nat Med (1999) 5(1):83-9. doi:10.1038/4772

26. Gorochov G, Neumann AU, Kereveur A, Parizot C, Li T, Katlama C, et al. Perturbation of CD4+ and CD8+ T-cell repertoires during progression to AIDS and regulation of the CD4+ repertoire during antiviral therapy. Nat Med (1998) 4(2):215-21. doi:10.1038/nm0298-215

27. Fevrier M, Dorgham K, Rebollo A. CD4+ T cell depletion in human immunodeficiency virus (HIV) infection: role of apoptosis. Viruses (2011) 3(5):586-612. doi:10.3390/v3050586

28. Deeks SG, Kitchen CM, Liu L, Guo H, Gascon R, Narvaez AB, et al. Immune activation set point during early HIV infection predicts subsequent CD4+ T-cell changes independent of viral load. Blood (2004) 104(4):942-7. doi:10.1182/blood-2003-09-3333

29. Rodriguez B, Sethi AK, Cheruvu VK, Mackay W, Bosch RJ, Kitahata M, et al. Predictive value of plasma HIV RNA level on rate of CD4 T-cell decline in untreated HIV infection. JAMA (2006) 296(12):1498-506. doi:10.1001/ jama.296.12.1498

30. Yates A, Stark J, Klein N, Antia R, Callard R. Understanding the slow depletion of memory CD4+ T cells in HIV infection. PLoS Med (2007) 4(5):e177. doi:10.1371/journal.pmed.0040177

31. De Boer RJ. Estimating the role of thymic output in HIV infection. Curr Opin HIV AIDS (2006) 1(1):16-21. doi:10.1097/01.COH.0000194105.12816.6a

32. Deeks SG, Walker BD. The immune response to AIDS virus infection: good, bad, or both? J Clin Invest (2004) 113(6):808-10. doi:10.1172/JCI21318

33. Hazenberg MD, Otto SA, van Benthem BH, Roos MT, Coutinho RA, Lange JM, et al. Persistent immune activation in HIV-1 infection is associated with 
progression to AIDS. AIDS (2003) 17(13):1881-8. doi:10.1097/01.aids. 0000076311.76477.6e

34. Giorgi JV, Hultin LE, McKeating JA, Johnson TD, Owens B, Jacobson LP, et al. Shorter survival in advanced human immunodeficiency virus type 1 infection is more closely associated with T lymphocyte activation than with plasma virus burden or virus chemokine coreceptor usage. J Infect Dis (1999) 179(4):859-70. doi:10.1086/314660

35. Sodora DL, Silvestri G. Immune activation and AIDS pathogenesis. AIDS (2008) 22(4):439-46. doi:10.1097/QAD.0b013e3282f2dbe7

36. Swingler S, Mann A, Jacque J, Brichacek B, Sasseville VG, Williams K, et al. HIV-1 Nef mediates lymphocyte chemotaxis and activation by infected macrophages. Nat Med (1999) 5(9):997-1003. doi:10.1038/12433

37. Unutmaz D, Pileri P, Abrignani S. Antigen-independent activation of naive and memory resting T cells by a cytokine combination. JExp Med (1994) 180(3):1159-64. doi:10.1084/jem.180.3.1159

38. O'Brien M, Manches O, Bhardwaj N. Plasmacytoid dendritic cells in HIV infection. Adv Exp Med Biol (2013) 762:71-107. doi:10.1007/978-1-4614-4433-6_3

39. Valdez H, Lederman MM. Cytokines and cytokine therapies in HIV infection. AIDS Clin Rev (1997):187-228.

40. Appay V, Sauce D. Immune activation and inflammation in HIV-1 infection: causes and consequences. J Pathol (2008) 214:231-41. doi:10.1002/ path. 2276

41. Liu Z, Cumberland WG, Hultin LE, Kaplan AH, Detels R, Giorgi JV. CD8+ T-lymphocyte activation in HIV-1 disease reflects an aspect of pathogenesis distinct from viral burden and immunodeficiency. J Acquir Immune Defic Syndr Hum Retrovirol (1998) 18(4):332-40. doi:10.1097/00042560199808010-00004

42. Younes SA, Yassine-Diab B, Dumont AR, Boulassel MR, Grossman Z, Routy JP, et al. HIV-1 viremia prevents the establishment of interleukin 2-producing HIV-specific memory CD4+ T cells endowed with proliferative capacity. J Exp Med (2003) 198(12):1909-22. doi:10.1084/jem.20031598

43. Harari A, Vallelian F, Pantaleo G. Phenotypic heterogeneity of antigen-specific $\mathrm{CD} 4 \mathrm{~T}$ cells under different conditions of antigen persistence and antigen load. Eur J Immunol (2004) 34(12):3525-33. doi:10.1002/eji.200425324

44. Birx DL, Redfield RR, Tencer K, Fowler A, Burke DS, Tosato G. Induction of interleukin-6 during human immunodeficiency virus infection. Blood (1990) 76(11):2303-10.

45. Molina JM, Scadden DT, Byrn R, Dinarello CA, Groopman JE. Production of tumor necrosis factor alpha and interleukin 1 beta by monocytic cells infected with human immunodeficiency virus. JClin Invest (1989) 84(3):733-7. doi:10.1172/JCI114230

46. Emilie D, Peuchmaur M, Maillot MC, Crevon MC, Brousse N, Delfraissy JF, et al. Production of interleukins in human immunodeficiency virus-1-replicating lymph nodes. JClin Invest (1990) 86(1):148-59. doi:10.1172/ JCI114678

47. van Wijk F, Cheroutre H. Mucosal T cells in gut homeostasis and inflammation. Expert Rev Clin Immunol (2010) 6(4):559-66. doi:10.1586/eci.10.34

48. Mattapallil JJ, Douek DC, Hill B, Nishimura Y, Martin M, Roederer M. Massive infection and loss of memory CD4+ T cells in multiple tissues during acute SIV infection. Nature (2005) 434(7037):1093-7. doi:10.1038/nature03501

49. Ruemmele FM, Beaulieu JF, Dionne S, Levy E, Seidman EG, Cerf-Bensussan N, et al. Lipopolysaccharide modulation of normal enterocyte turnover by tolllike receptors is mediated by endogenously produced tumour necrosis factor alpha. Gut (2002) 51(6):842-8. doi:10.1136/gut.51.6.842

50. Sandler NG, Douek DC. Microbial translocation in HIV infection: causes, consequences and treatment opportunities. Nat Rev Microbiol (2012) 10(9):655-66. doi:10.1038/nrmicro2848

51. Doitsh G, Cavrois M, Lassen KG, Zepeda O, Yang Z, Santiago ML, et al. Abortive HIV infection mediates CD4 T cell depletion and inflammation in human lymphoid tissue. Cell (2010) 143(5):789-801. doi:10.1016/j.cell. 2010.11.001

52. Doitsh G, Galloway NL, Geng X, Yang Z, Monroe KM, Zepeda O, et al. Cell death by pyroptosis drives CD4 T-cell depletion in HIV-1 infection. Nature (2014) 505(7484):509-14. doi:10.1038/nature12940

53. Sakaguchi S. Control of immune responses by naturally arising CD4+ regulatory T cells that express toll-like receptors. J Exp Med (2003) 197(4):397-401. doi:10.1084/jem.20030012

54. Foxall RB, Albuquerque AS, Soares RS, Baptista AP, Cavaleiro R, Tendeiro R, et al. Memory and naive-like regulatory $\mathrm{CD} 4+\mathrm{T}$ cells expand during
HIV-2 infection in direct association with CD4+ T-cell depletion irrespectively of viremia. AIDS (2011) 25(16):1961-70. doi:10.1097/ QAD.0b013e32834b3554

55. Eggena MP, Barugahare B, Jones N, Okello M, Mutalya S, Kityo C, et al. Depletion of regulatory $\mathrm{T}$ cells in HIV infection is associated with immune activation. J Immunol (2005) 174(7):4407-14. doi:10.4049/jimmunol.174.7. 4407

56. Cavaleiro R, Brunn GJ, Albuquerque AS, Victorino RM, Platt JL, Sousa AE. Monocyte-mediated T cell suppression by HIV-2 envelope proteins. Eur J Immunol (2007) 37(12):3435-44. doi:10.1002/eji.200737511

57. Clavel F, Mansinho K, Chamaret S, Guetard D, Favier V, Nina J, et al. Human immunodeficiency virus type 2 infection associated with AIDS in West Africa. N Engl J Med (1987) 316(19):1180-5. doi:10.1056/NEJM198705073161903

58. Bock PJ, Markovitz DM. Infection with HIV-2. AIDS (2001) 15(Suppl 5): S35-45. doi:10.1097/00002030-200100005-00006

59. Sousa AE, Carneiro J, Meier-Schellersheim M, Grossman Z, Victorino RM. $\mathrm{CD} 4 \mathrm{~T}$ cell depletion is linked directly to immune activation in the pathogenesis of HIV-1 and HIV-2 but only indirectly to the viral load. J Immunol (2002) 169(6):3400-6. doi:10.4049/jimmunol.169.6.3400

60. Miedema F, Hazenberg MD, Tesselaar K, van Baarle D, de Boer RJ, Borghans JA. Immune activation and collateral damage in AIDS pathogenesis. Front Immunol (2013) 4:298. doi:10.3389/fimmu.2013.00298

61. Funderburg N, Luciano AA, Jiang W, Rodriguez B, Sieg SF, Lederman MM. Toll-like receptor ligands induce human $\mathrm{T}$ cell activation and death, a model for HIV pathogenesis. PLoS One (2008) 3(4):e1915. doi:10.1371/journal. pone. 0001915

62. Mogensen TH, Melchjorsen J, Larsen CS, Paludan SR. Innate immune recognition and activation during HIV infection. Retrovirology (2010) 7:54. doi:10.1186/1742-4690-7-54

63. Nowroozalizadeh S, Mansson F, da Silva Z, Repits J, Dabo B, Pereira C, et al. Microbial translocation correlates with the severity of both HIV-1 and HIV-2 infections. J Infect Dis (2010) 201(8):1150-4. doi:10.1086/651430

64. Johnson WE, Desrosiers RC. Viral persistence: HIV's strategies of immune system evasion. Аnnu Rev Med (2002) 53:499-518. doi:10.1146/annurev. med.53.082901.104053

65. Michael NL, Morrow P, Mosca J, Vahey M, Burke DS, Redfield RR. Induction of human immunodeficiency virus type 1 expression in chronically infected cells is associated primarily with a shift in RNA splicing patterns. J Virol (1991) 65(3):1291-303.

66. Soares RS, Tendeiro R, Foxall RB, Baptista AP, Cavaleiro R, Gomes P, et al. Cell-associated viral burden provides evidence of ongoing viral replication in aviremic HIV-2-infected patients. J Virol (2011) 85(5):2429-38. doi:10.1128/ JVI.01921-10

67. Hanson A, Sarr AD, Shea A, Jones N, Mboup S, Kanki P, et al. Distinct profile of T cell activation in HIV type 2 compared to HIV type 1 infection: differential mechanism for immunoprotection. AIDS Res Hum Retroviruses (2005) 21(9):791-8. doi:10.1089/aid.2005.21.791

68. Alatrakchi N, Damond F, Matheron S, Beretta-Tempelhoff S, Campa P, Carcelain G, et al. Proliferative, IFNgamma and IL-2-producing T-cell responses to HIV-2 in untreated HIV-2 infection. AIDS (2006) 20(1):29-34. doi:10.1097/01.aids.0000198077.30421.bf

69. Hamann D, Baars PA, Rep MH, Hooibrink B, Kerkhof-Garde SR, Klein MR, et al. Phenotypic and functional separation of memory and effector human CD8+ T cells. J Exp Med (1997) 186(9):1407-18. doi:10.1084/ jem.186.9.1407

70. Adachi Y, Oyaizu N, Than S, McCloskey TW, Pahwa S. IL-2 rescues in vitro lymphocyte apoptosis in patients with HIV infection: correlation with its ability to block culture-induced down-modulation of Bcl-2.J Immunol (1996) 157(9):4184-93.

71. Sousa AE, Chaves AF, Loureiro A, Victorino RM. Comparison of the frequency of interleukin (IL)-2-, interferon-gamma-, and IL-4-producing T cells in 2 diseases, human immunodeficiency virus types 1 and 2, with distinct clinical outcomes. J Infect Dis (2001) 184(5):552-9. doi:10.1086/322804

72. Jaleco AC, Covas MJ, Victorino RM. Analysis of lymphocyte cell death and apoptosis in HIV-2-infected patients. Clin Exp Immunol (1994) 98(2):185-9. doi:10.1111/j.1365-2249.1994.tb06123.x

73. Michel P, Balde AT, Roussilhon C, Aribot G, Sarthou JL, Gougeon ML. Reduced immune activation and $\mathrm{T}$ cell apoptosis in human immunodeficiency virus type 2 compared with type 1: correlation of $\mathrm{T}$ cell apoptosis with 
beta2 microglobulin concentration and disease evolution. J Infect Dis (2000) 181(1):64-75. doi:10.1086/315170

74. Duvall MG, Jaye A, Dong T, Brenchley JM, Alabi AS, Jeffries DJ, et al. Maintenance of HIV-specific CD4+ $\mathrm{T}$ cell help distinguishes HIV-2 from HIV-1 infection. JImmunol (2006) 176(11):6973-81. doi:10.4049/ jimmunol.176.11.6973

75. Kovacs JA, Lempicki RA, Sidorov IA, Adelsberger JW, Sereti I, Sachau W, et al. Induction of prolonged survival of $\mathrm{CD} 4+\mathrm{T}$ lymphocytes by intermittent IL-2 therapy in HIV-infected patients. J Clin Invest (2005) 115(8):2139-48. doi:10.1172/JCI23196

76. Goldstone DC, Ennis-Adeniran V, Hedden JJ, Groom HC, Rice GI, Christodoulou E, et al. HIV-1 restriction factor SAMHD1 is a deoxynucleoside triphosphate triphosphohydrolase. Nature (2011) 480(7377):379-82. doi:10.1038/nature10623

77. Lahaye X, Satoh T, Gentili M, Cerboni S, Conrad C, Hurbain I, et al. The capsids of HIV- 1 and HIV-2 determine immune detection of the viral cDNA by the innate sensor cGAS in dendritic cells. Immunity (2013) 39(6):1132-42. doi:10.1016/j.immuni.2013.11.002

78. Granelli-Piperno A, Golebiowska A, Trumpfheller C, Siegal FP, Steinman RM. HIV-1-infected monocyte-derived dendritic cells do not undergo maturation but can elicit IL-10 production and T cell regulation. Proc Natl Acad Sci U S A (2004) 101:7669-74. doi:10.1073/pnas.0402431101

79. Manel N, Hogstad B, Wang Y, Levy DE, Unutmaz D, Littman DR. A cryptic sensor for HIV-1 activates antiviral innate immunity in dendritic cells. Nature (2010) 467(7312):214-7. doi:10.1038/nature09337

80. Mandl JN, Barry AP, Vanderford TH, Kozyr N, Chavan R, Klucking S, et al. Divergent TLR7 and TLR9 signaling and type I interferon production distinguish pathogenic and nonpathogenic AIDS virus infections. Nat Med (2008) 14(10):1077-87. doi:10.1038/nm.1871

81. Cavaleiro R, Baptista AP, Soares RS, Tendeiro R, Foxall RB, Gomes P, et al. Major depletion of plasmacytoid dendritic cells in HIV-2 infection, an attenuated form of HIV disease. PLoS Pathog (2009) 5(11):e1000667. doi:10.1371/ journal.ppat.1000667

82. Chun TW, Davey RT Jr, Engel D, Lane HC, Fauci AS. Re-emergence of HIV after stopping therapy. Nature (1999) 401(6756):874-5. doi:10.1038/44755

83. Ramratnam B, Mittler JE, Zhang L, Boden D, Hurley A, Fang F, et al. The decay of the latent reservoir of replication-competent HIV-1 is inversely correlated with the extent of residual viral replication during prolonged anti-retroviral therapy. Nat Med (2000) 6(1):82-5. doi:10.1038/71577

84. Nunes-Cabaco H, Matoso P, Foxall RB, Tendeiro R, Pires AR, Carvalho T, et al. Thymic HIV-2 infection uncovers posttranscriptional control of viral replication in human thymocytes. J Virol (2015) 89(4):2201-8. doi:10.1128/ JVI.03047-14

Conflict of Interest Statement: The authors declare that the research was conducted in the absence of any commercial or financial relationships that could be construed as a potential conflict of interest.

Copyright (c) 2017 Vidya Vijayan, Karthigeyan, Tripathi and Hanna. This is an open-access article distributed under the terms of the Creative Commons Attribution License (CC BY). The use, distribution or reproduction in other forums is permitted, provided the original author(s) or licensor are credited and that the original publication in this journal is cited, in accordance with accepted academic practice. No use, distribution or reproduction is permitted which does not comply with these terms. 